\title{
TRACE ELEMENT ANALYSIS IN PROVENANCING ROMAN GLASS-MAKING*
}

\author{
D. BREMS $\dagger$ and P. DEGRYSE \\ KU Leuven, Department of Earth and Environmental Sciences, Division of Geology, Celestijnenlaan 200E, \\ B-3001 Leuven, Belgium
}

\begin{abstract}
In this study, the use of trace elements as a provenance indicator for Roman natron glass is evaluated. Suitable glass-making sand raw materials are analysed for their trace elemental composition and compared to glass from known production centres. It is shown that the combined use of Nd isotopic and trace element analysis can be efficient for the provenancing of Roman glass. Trace elements associated with (de)colourants of glass are only present in small concentrations in glass-making sands. Background levels introduced to the glass by the sand raw material are defined and a lower threshold for the concentrations influenced by recycling is determined.
\end{abstract}

KEYWORDS: TRACE ELEMENTS, Nd ISOTOPES, PROVENANCE STUDIES, ROMAN, NATRON GLASS, RAW MATERIALS, BEACH SAND, WESTERN MEDITERRANEAN, INAA

\section{INTRODUCTION}

After decades of research, it still remains difficult to determine the primary provenance of Roman natron glass. This type of material was made by melting three components (i.e., quartz sand, natron and lime) at temperatures of about $1100^{\circ} \mathrm{C}$ (Gorin-Rosen 2000). During the production of natron glass, the raw materials are completely transformed and all their visible characteristics are lost, leaving only bulk chemical data as a potential discriminating feature. Unfortunately, the compositional variation of soda-lime-silica glass is limited due to the maximum attainable furnace temperatures and the shape of the $\mathrm{Na}_{2} \mathrm{O}-\mathrm{SiO}_{2}-\mathrm{CaO}$ ternary phase diagram (Shahid and Glasser 1972). As a result, all Roman glass is relatively uniform in its major elemental composition (Sayre and Smith 1961; Freestone 2006). On top of that, raw glass is reworked into objects in secondary workshops, which are not necessarily located close to the primary origin of the glass (Freestone et al. 2002b). During this process, raw glass from different sources can be mixed and colouring agents can be added, introducing a wide variety of chemical elements. Furthermore, glass fragments or cullet can be recycled at any stage. During the past few years, however, studies on the provenance determination of ancient glass have revived due to the introduction of trace element and isotope analysis (Wedepohl and Baumann 2000; Freestone et al. 2003; Degryse et al. 2006; Shortland et al. 2007; Degryse and Schneider 2008; Degryse and Shortland 2009; Brems et al. 2013a,b).

During the Late Roman and Byzantine periods, raw glass appears to have been produced exclusively in a small number of primary production centres in Israel and Egypt (Gorin-Rosen 1995, 2000; Freestone et al. 2000, 2002a,b). Analytical data suggest that during the Hellenistic and Early Roman periods, natron glass production also took place in the western part of the 
Roman Empire (Degryse and Schneider 2008; Brems et al. 2012b). However, the exact location of any primary production centres in these regions remains unknown. Recently, a limited number of potential sources of suitable glass-making sand raw materials were identified along the coasts of Spain, France and Italy (Brems et al. 2012a,c), indicating that the necessary materials for glass production were indeed available in these parts of the Empire. In this paper, we present the trace elemental composition of these sand raw materials, and we investigate whether a distinction can be made between these possible source areas and glass from the known primary production centres in the eastern Mediterranean on the basis of trace element geochemistry.

\section{TRACE ELEMENTS IN ROMAN GLASS}

Roman natron glass can be seen as a mixture of three components: silica sand, lime-bearing material and natron as the soda-rich flux. Additionally, glass was often coloured or decoloured by adding a small amount of specific minerals. These raw materials all introduced a number of trace elements to the glass batch (Fig. 1). In particular, those solely related to the sand raw material are of interest as possible provenance indicators.

\section{Natron}

Natron was a relatively pure source of soda, found in evaporitic lakes. It was composed of sodium carbonates (trona, natron and nahcolite), sulphates (thenardite, burkeite and mirabilite), chlorides (halite) and insoluble material (quartz and clay) in varying proportions (Shortland 2004; Shortland et al. 2006, 2011; Currie 2008). Depending on the mineralogy of the evaporitic deposits, the concentration of elements such as Cl and S varies greatly (Brill 1999; Currie 2008; Shortland et al. unpublished data). These elements were probably almost entirely introduced to the glass batch by the natron flux. The concentration of $\mathrm{Cl}$ and $\mathrm{S}$ in the final glass is, however, limited by their solubility in soda-lime-silica melts (Bateson and Turner 1939; Gerth et al. 1998; Köpsel 2001; Shugar and Rehren 2002; Salviulo et al. 2004). The concentration of most other commonly measured trace elements in both modern and ancient evaporites from the Wadi Natrun is found to be very low (Currie 2008; Wedepohl et al. 2011b; Shortland et al. unpublished data). When compared with the concentration of trace elements in natron glass as given by, for example, Degryse and Shortland (2009) and Wedepohl et al. (2011a), only B, P, Br and U appear to occur in the same order of magnitude in both natron and natron glass. $\mathrm{Mg}$ concentrations are 30 times lower in the flux. The concentration of elements such as $\mathrm{Li}, \mathrm{K}, \mathrm{V}, \mathrm{Cr}, \mathrm{Ni}, \mathrm{Cu}, \mathrm{Zn}, \mathrm{Sr}, \mathrm{Zr}, \mathrm{Ba}, \mathrm{Pb}$ and the rare earth elements (REE) are between 60 and 1500 times lower in natron than in average natron glass (Currie 2008; Wedepohl et al. 2011b; Shortland et al. unpublished data).

\section{Sand}

Because of the small ionic size of $\mathrm{Si}^{4+}(0.026 \mathrm{~nm})$ (Shannon 1976), only very small amounts of other elements such as $\mathrm{Al}, \mathrm{Ti}, \mathrm{Fe}$ and $\mathrm{Ge}$ can be incorporated into the crystal structure of quartz. Minor and trace elements in quartz-rich sands are generally concentrated in associated accessory minerals such as feldspar, pyroxene, amphibole, zircon, Fe-Ti oxides, monazite and clay minerals, among others. Sand deposits can contain different types and quantities of accessory minerals, depending on the nature of the source rocks and the local geological setting. Different mineralogical compositions of the sands will lead to different trace element signatures, which may be useful tracers for their origin. 
Trace element analysis in provenancing Roman glass-making

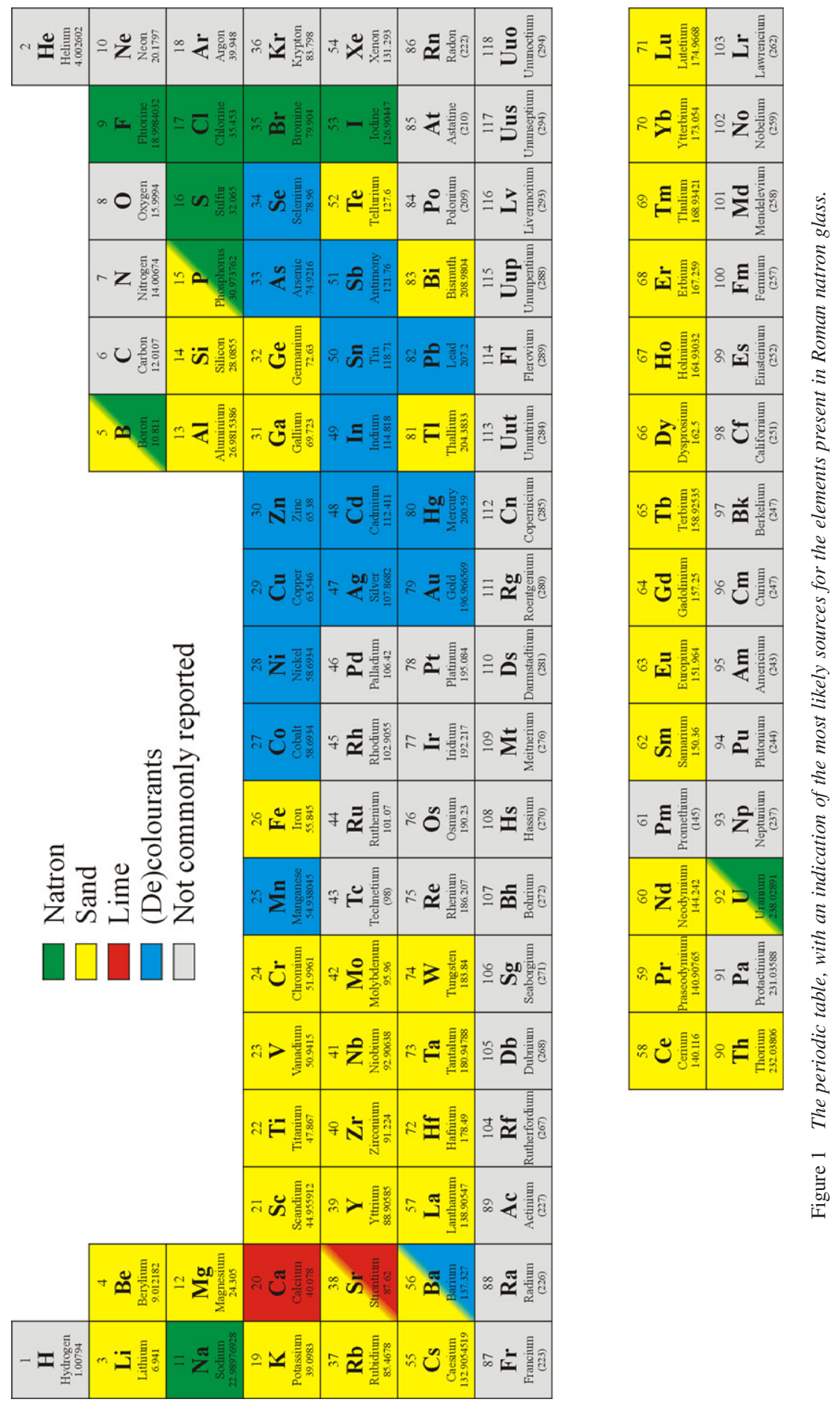


The application of trace elements as provenance indicators for ancient glass was explored in recent studies. Roman natron glass generally contains relatively low levels of trace elements. This is attributed to the use of mineralogically mature sand, rich in quartz and relatively depleted in heavy minerals (Freestone et al. 2000, 2002b). HIMT glass typically contains higher concentrations of trace elements, suggesting the use of less pure quartz sands (Freestone et al. 2005). Promising groupings of glass could be made based on elements such as Zr-Ti (Aerts et al. 2003), $\mathrm{Zr}-\mathrm{Ti}-\mathrm{Cr}-\mathrm{La}$ (Shortland et al. 2007; Reade 2009; Walton et al. 2009) and Zr-Sr-Ba (Freestone et al. 2000; Paynter 2006; Silvestri 2008; Silvestri et al. 2008). In most cases, these elements can be used to distinguish between different sand raw materials, since they are usually not related to the (de)colouring agents that could have been deliberately added to the glass batch. However, for $\mathrm{Mn}$-decoloured glass, caution is in order. Mn ores are likely to introduce some minor amounts of Ba (Brill 1988; Jackson 2005; Paynter 2006; Silvestri 2008; Foster and Jackson 2010) and possibly Sr (Ganio et al. 2012) to the glass. Zr, together with Hf, is accumulated in the heavy mineral zircon. Trace elements such as $\mathrm{Sc}, \mathrm{Ti}, \mathrm{V}$ and $\mathrm{Cr}$ are generally correlated with iron oxides (Wedepohl et al. 2011a) or with specific heavy minerals such as rutile, ilmenite, titanite and chromite. $\mathrm{Ba}$ and $\mathrm{Rb}$ are related to alkali feldspar. Wedepohl and Baumann (2000) attributed relatively high $\mathrm{Ba}$ concentrations in Roman glass from Hambach to the presence of barite as a heavy mineral in the glass-making sand. Ga substitutes for $\mathrm{Al}$ in aluminium silicates (Wedepohl et al. 2011a). Other elements that are probably also related to the sand raw materials are $\mathrm{Li}, \mathrm{Be}$, Ge, Y, Nb, Mo, Te, Cs, La, Ta, W, Tl, Bi and Th (Shortland et al. 2007; Degryse and Shortland 2009; Reade 2009; Wedepohl et al. 2011a,b). B, P and U are partly derived from the silica source (Shortland et al. 2007), but they also come in with the natron flux. Sr is provided by both the sand (i.e., mostly feldspar and mica) and the source of lime (Brems et al. 2013a). In Mn-rich glasses, some of the Sr may be introduced through the Mn ore (Ganio et al. 2012).

Rare earth elements (REE) are generally used as provenance indicators of sediments and sedimentary rocks (e.g., McLennan 1989; Lidiak and Jolly 1996). In quartz-rich sands, these elements are mostly concentrated in the clay and silt fraction (Cullers et al. 1979; Tlig and Steinberg 1982; McLennan 1989; Yokoo et al. 2004). However, heavy mineral species can also contain significant amounts of REE. The light REE are accumulated in monazite and allanite, while the heavy REE are relatively concentrated in zircon and garnet (Gromet and Silver 1983; McKay 1989; McLennan 1989). Unlike the other REE, Eu can occur in a divalent state and as a result, it can be preferentially incorporated in plagioclase. Enrichment or depletion in plagioclase during weathering, erosion or sedimentary processes can cause positive or negative $\mathrm{Eu}$ anomalies in the REE patterns of sandy sediments, which in turn can be passed on to the glass (for a more extensive discussion, see also Degryse and Shortland 2009; Wedepohl et al. 2011b). Average REE patterns appear to be distinctly different between three major ancient glass groups; that is, soda-ash glass, natron glass and wood-ash glass (Wedepohl et al. 2011b). However, within the group of natron glass, REE patterns are relatively uniform (Degryse and Shortland 2009; Wedepohl et al. 2011b). This would indicate that the REE are derived from the clay fraction of the sand raw materials or from interaction with the furnace walls, and are of little use as a provenance indicator for Roman natron glass (Degryse and Shortland 2009; Walton et al. 2009).

\section{Lime}

$\mathrm{Sr}$ in natron glass is mostly derived from the shell or limestone introduced (whether deliberately or not) as the source of lime (Wedepohl and Baumann 2000; Freestone et al. 2003; Brems et al. 
2013a). High Sr concentrations in glass suggest the use of shell fragments, while low Sr contents indicate the use of limestone. However, other mineral species in the sand raw material, such as feldspar and mica, can also introduce Sr to the glass (Degryse et al. 2006; Brems et al. 2013a). It has also been suggested that some of the $\mathrm{Sr}$ in glasses decolourized with $\mathrm{Mn}$ could have been introduced by the Mn ore (Ganio et al. 2012). The lime-bearing component of the glass batch can also introduce minor amounts of chemically related elements such as $\mathrm{Mg}$, Fe and $\mathrm{Mn}$. Rare earth elements and other trace elements only occur in very small concentrations in shell material (e.g., Wedepohl et al. 2011a,b).

\section{(De)colourants and recycling}

Pure soda-lime-silica glass, without any impurities, is essentially colourless. Most ancient glass fragments, however, contain a small amount of $\mathrm{Fe}_{2} \mathrm{O}_{3}$. This results in a green-blue tint. This iron was usually unintentionally introduced as impurities in the sand raw material. The green-blue colour could be neutralized by the addition of $\mathrm{Mn}$ or $\mathrm{Sb}$, which resulted in the oxidation of the $\mathrm{Fe}^{2+}$ to the practically colourless $\mathrm{Fe}^{3+}$ (Sayre and Smith 1961; Sayre 1963; Brill 1988). By adding different metals in varying concentrations and under different furnace conditions, a whole range of different colours could be achieved. Details of the effects of these different elements on the colour of glass are beyond the scope of this study and can be found in Weyl (1951), Bamford (1977), Green and Hart (1987) and Pollard and Heron (2008).

Elements commonly associated with (de)colouring in ancient glass are $\mathrm{Mn}, \mathrm{Co}, \mathrm{Ni}, \mathrm{Cu}, \mathrm{Zn}, \mathrm{As}$, $\mathrm{Se}, \mathrm{Ag}, \mathrm{Cd}, \mathrm{In}, \mathrm{Sn}, \mathrm{Sb}, \mathrm{Au}, \mathrm{Hg}$ and Pb (Aerts et al. 2003; Shortland et al. 2007; Degryse and Shortland 2009; Reade 2009; Wedepohl et al. 2011a). Some of these elements do not influence the colour of the glass, but they occur as impurities in the mineral (de)colourants. Elevated concentrations of these (de)colourant-related elements (over $1000 \mathrm{ppm}$ ) suggest that they were deliberately added to the glass batch to influence the colour of the resulting product. Concentrations between about $100 \mathrm{ppm}$ and $1000 \mathrm{ppm}$ are typically interpreted as indications for glass recycling (Freestone et al. 2002b; Silvestri et al. 2005; Degryse and Shortland 2009; Foster and Jackson 2010). Remelting of a batch of colourless cullet with small amounts of coloured fragments would result in concentrations of these colouring elements not high enough to significantly alter the colour and suggest intentional addition, but too high to be explained by natural impurities in the sand raw materials. Low concentrations $(<100 \mathrm{ppm})$ of trace elements such as $\mathrm{Co}, \mathrm{Cu}$, and $\mathrm{Pb}$ are said to suggest that the glass was produced from primary raw materials and that recycling was limited, or that recycling took place after very careful selection of cullet to avoid contamination (Silvestri 2008; Silvestri et al. 2008). These concentration boundaries are, however, arbitrary. Little is known about the actual background concentrations of (de)colourantrelated elements in glass-making sand raw materials.

Roman natron glasses decoloured by $\mathrm{Mn}$ often show elevated $\mathrm{Ba}$ contents and a strong positive correlation between Mn and Ba (Brill 1988; Paynter 2006; Foster and Jackson 2010). This is consistent with the use of wad or a mixture of pyrolusite $\left(\mathrm{MnO}_{2}\right)$ and psilomelane $\left(\left(\mathrm{Ba}, \mathrm{H}_{2} \mathrm{O}\right)_{2} \mathrm{Mn}_{5} \mathrm{O}_{10}\right)$ as the source of Mn (Jackson 2005; Silvestri 2008). Next to Ba, the Mn source may also introduce extra $\mathrm{Sr}$ to the glass (Ganio et al. 2012).

\section{OBJECTIVES AND METHODS}

The trace elemental composition of natron glass will be a combination of elements present in the sand, the natron and the lime, and possibly any (de)colourants that were added to the glass batch. 
In this study, we investigate the variation in trace element signatures of 11 potential glass-making sand raw materials (Fig. 2 and Table 1). The analysed samples belong to a much larger set of 178 beach sand samples from the Mediterranean coasts of Spain, France and Italy, which were previously evaluated for their suitability for natron glass production (Brems et al. 2012c). The major elemental compositions of these sands were used to calculate the compositions of glass that

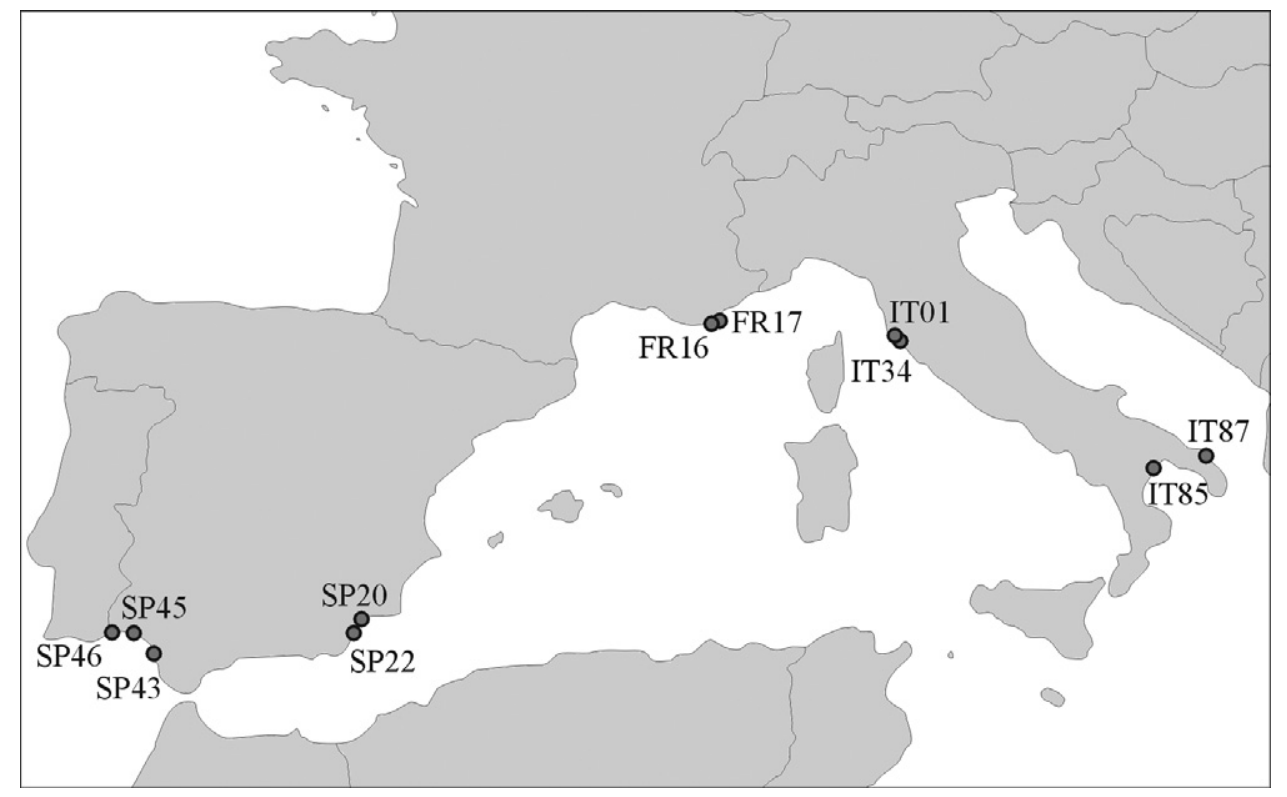

Figure 2 A map of the western Mediterranean, showing the sample locations of the beach sands analysed.

Table 1 Sampling locations of beach sands analysed in this study

\begin{tabular}{|c|c|c|c|}
\hline Sample & Location & Latitude $\left({ }^{\circ} \mathrm{N}\right)$ & Longitude $\left({ }^{\circ} E\right)$ \\
\hline \multicolumn{4}{|l|}{ Spain } \\
\hline SP46 & Isla Canela & $\mathrm{N} 37^{\circ} 10^{\prime} 34.08^{\prime \prime}$ & $\mathrm{W} 007^{\circ} 21^{\prime} 15.58^{\prime \prime}$ \\
\hline SP45 & Mazagón & $\mathrm{N} 37^{\circ} 07^{\prime} 44.86^{\prime \prime}$ & W006 $49^{\prime} 29.42^{\prime \prime}$ \\
\hline SP43 & Sanlúcar de Barrameda & $\mathrm{N} 36^{\circ} 46^{\prime} 48.43^{\prime \prime}$ & W006 $21^{\prime} 59.54^{\prime \prime}$ \\
\hline SP22 & Las Marinas de Vera (Garrucha) & $\mathrm{N} 37^{\circ} 11^{\prime} 50.56^{\prime \prime}$ & W00 $1^{\circ} 48^{\prime} 44.82^{\prime \prime}$ \\
\hline SP20 & El Rubial & $\mathrm{N} 37^{\circ} 24^{\prime} 02.10^{\prime \prime}$ & W001 $35^{\prime} 33.26^{\prime \prime}$ \\
\hline \multicolumn{4}{|c|}{ France } \\
\hline FR16 & Les Bormettes, La Londe-les-Maures & $\mathrm{N} 43^{\circ} 07^{\prime} 16.69^{\prime \prime}$ & $\mathrm{E} 006^{\circ} 15^{\prime} 38.86^{\prime \prime}$ \\
\hline FR17 & Cavalaire-sur-Mer & $\mathrm{N} 43^{\circ} 10^{\prime} 57.28^{\prime \prime}$ & $\mathrm{E} 006^{\circ} 32^{\prime} 28.29^{\prime \prime}$ \\
\hline \multicolumn{4}{|l|}{ Italy } \\
\hline IT34 & Torre del Sale, Piombino & $\mathrm{N} 42^{\circ} 57^{\prime} 14.50^{\prime \prime}$ & $\mathrm{E} 010^{\circ} 36^{\prime} 00.71^{\prime \prime}$ \\
\hline IT01 & Cala Violina & $\mathrm{N} 42^{\circ} 50^{\prime} 19.53^{\prime \prime}$ & $\mathrm{E} 010^{\circ} 46^{\prime} 29.46^{\prime \prime}$ \\
\hline IT85 & Metaponto Lido & $\mathrm{N} 40^{\circ} 20^{\prime} 34.11^{\prime \prime}$ & $\mathrm{E} 016^{\circ} 49^{\prime} 23.68^{\prime \prime}$ \\
\hline IT87 & Masseria Maime & $\mathrm{N} 40^{\circ} 33^{\prime} 27.00^{\prime \prime}$ & $\mathrm{E} 018^{\circ} 02^{\prime} 36.73^{\prime \prime}$ \\
\hline Shell & $\begin{array}{l}\text { Mixture of shell fragments from southern France and } \\
\text { north-western Italy }\end{array}$ & - & - \\
\hline
\end{tabular}


could be produced after the addition of pure natron. These compositions were then compared to the average composition of Roman natron glass. The 11 beach sands under investigation in the present study were found to be the most suitable for the production of natron glass, with or without the need for an extra source of lime (Brems et al. 2012c). Sand deposits from specific beaches in Basilicata (sand sample IT85), Puglia (IT87) and Tuscany (IT34) are suitable for the production of natron glass in their present form. Sands from particular locations in the province of Huelva (SP46, SP45 and SP43), the Murcia region (SP22 and SP20) and Provence (FR16 and FR17) contain insufficient $\mathrm{CaO}$ to produce a stable glass. However, after the addition of an extra source of lime, these sands can be melted into glass that would show a very close resemblance to Imperial Roman natron glass (Brems et al. 2012c). By determining their trace elemental composition, we can examine whether the elements commonly attributed to the sand raw material can be used to distinguish between these potential sources of natron glass and raw glass from the known primary production centres in the Levant and Egypt. The concentrations of trace elements generally associated with (de)colouring agents will provide more information about the background levels for these elements that are attributable to the sand raw materials. A mixture of shell material collected from several beaches along the Mediterranean coast of France and north-west Italy was also included in the analysis to investigate the possible influence of the addition of extra shell fragments on the final bulk trace element signature of a glass batch.

Sand and shell samples were finely crushed in an agate mortar and analysed for their trace elemental composition using instrumental neutron activation analysis (INAA) at the Interfaculty Reactor Institute of the Delft University of Technology, the Netherlands (Bode 1990; Greenberg et al. 2011). About $200 \mathrm{mg}$ of sample material was weighed and packed in high-purity polyethylene capsules. Together with a standard and blank, the capsules containing the samples were sealed in polyethylene foil and packed in an irradiation container. This container was irradiated by bringing it near the reactor core using a pneumatic irradiation tube system. After irradiation, the samples were unpacked and the emitted gamma radiation was measured using a semiconductor gamma-ray spectrometer. Results were processed using a UNIX-based computer system.

\section{RESULTS AND DISCUSSION}

The results of the trace element analysis of the suitable glass-making sands and the shell fragments are listed in Table 2. This table also contains previously unpublished trace elemental data for a sand sample from the mouth of the River Belus, sampled by R. H. Brill in the 1960s (Brill 1999) and analysed via ICP-MS by Degryse. Table 3 shows the correlation matrix for the trace elements analysed by INAA and major and minor elements previously determined via ICP-OES (methodology and data published by Brems et al. 2012c). Elements for which the concentration was above the detection limit for only three samples or less were discarded. For $\mathrm{Br}$, measurable concentrations were detected in only four sand samples, so any correlations found with this element must be evaluated carefully to rule out any errors due to the small amount of data points.

\section{Natron-related elements}

The elements $\mathrm{Na}, \mathrm{Cl}, \mathrm{S}, \mathrm{P}, \mathrm{F}, \mathrm{Br}, \mathrm{I}, \mathrm{B}$ and $\mathrm{U}$ in natron glass are fully or partially attributed to the natron flux used (Fig. 1). Of these elements, $\mathrm{Na}$ and $\mathrm{P}$ were previously analysed via ICP-OES and discussed in Brems et al. (2012c). Cl, Br and I could be analysed using INAA. Cl concentrations 


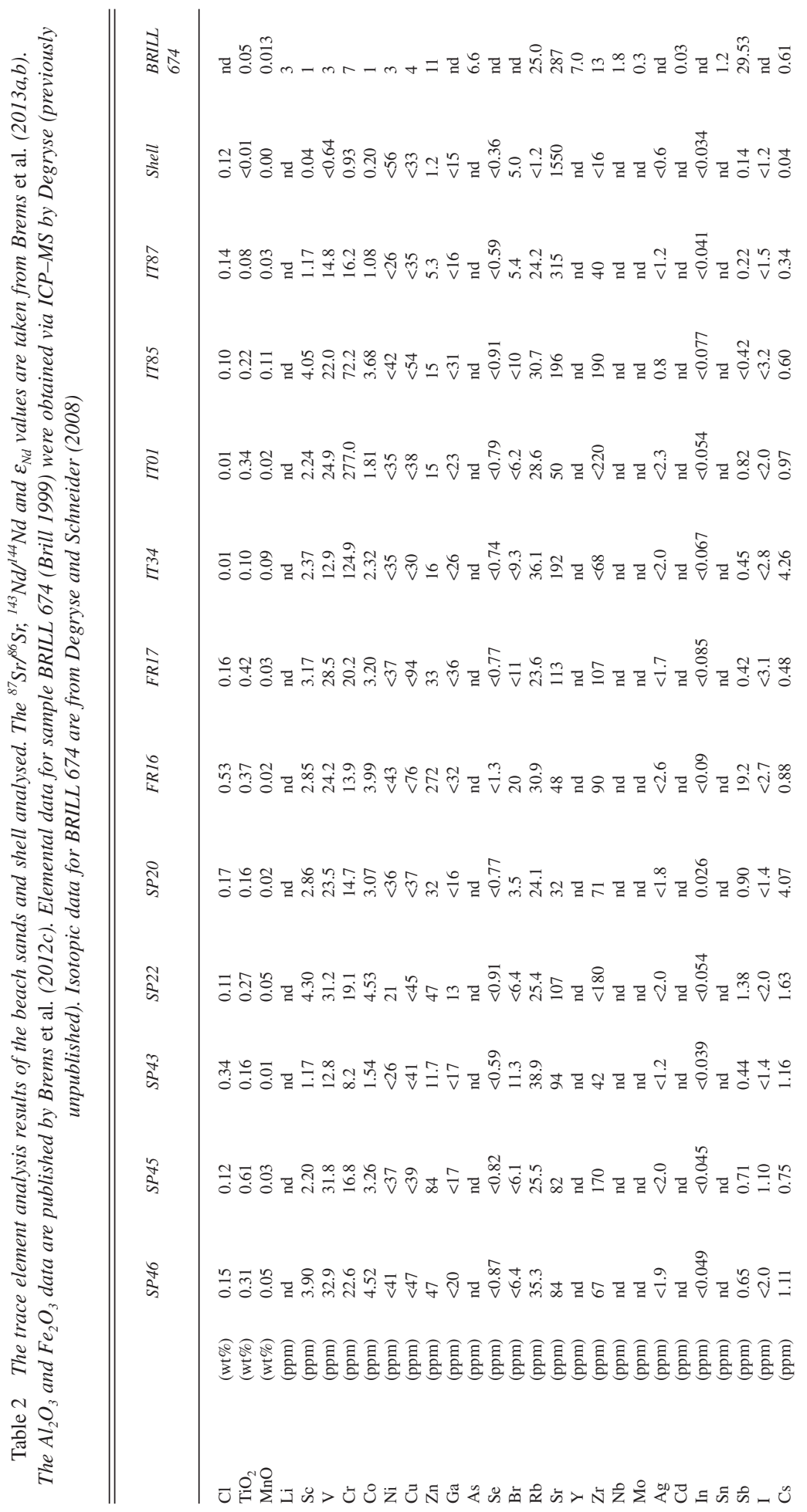




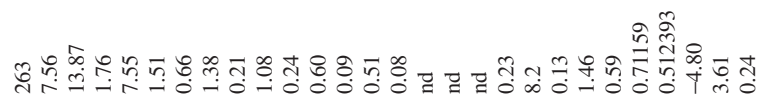

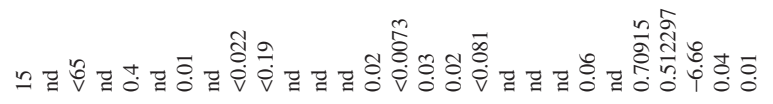

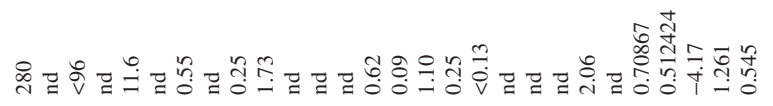

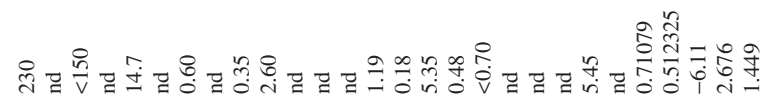

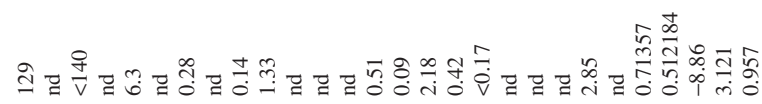

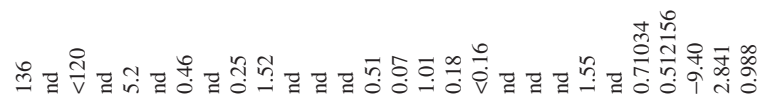

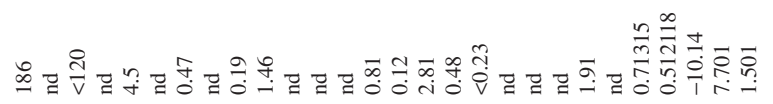

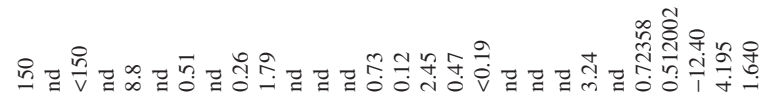

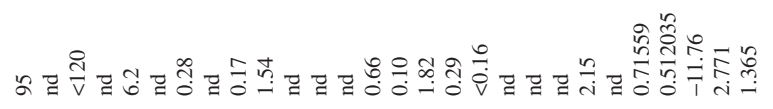

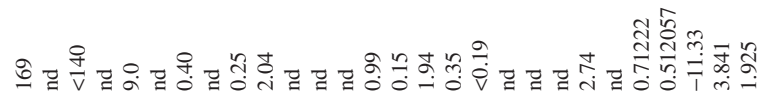

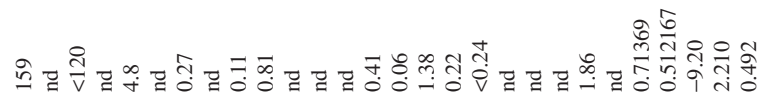

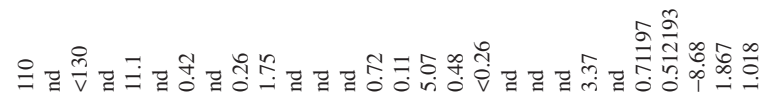

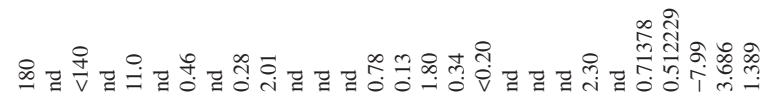

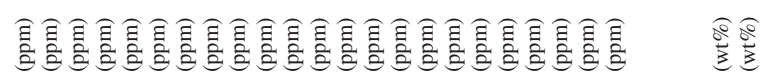

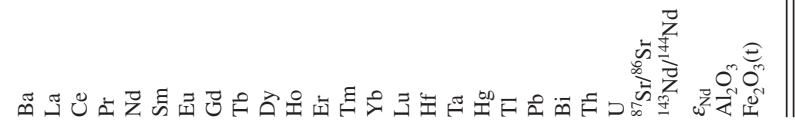




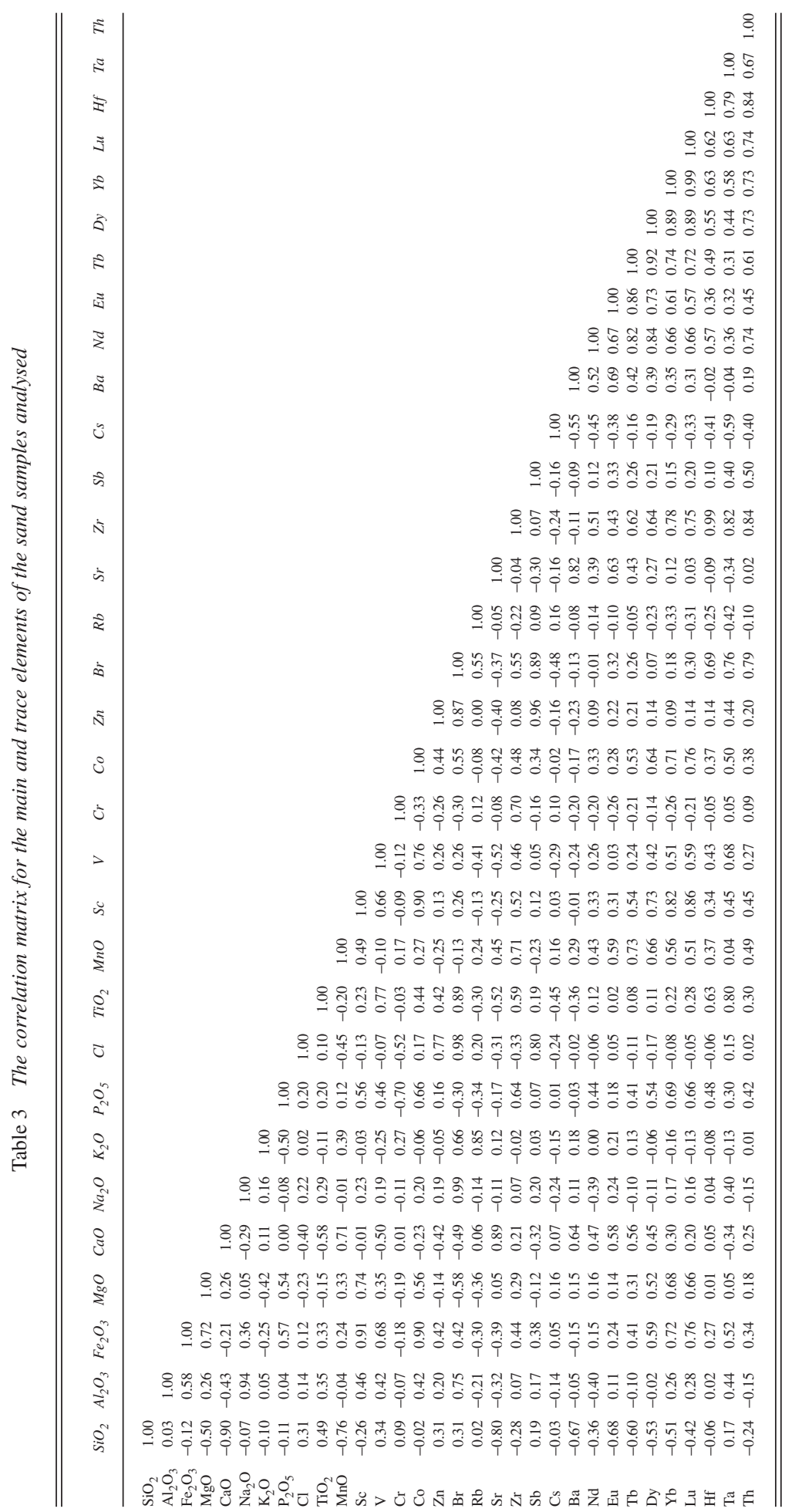


in the analysed sand samples vary between 0.01 and $0.53 \%$. This variation is a result of the varying amounts of halite from the seawater adhering to the beach sand grains. Concentrations of $\mathrm{Br}$ in the beach sands range from below detection limit to $20 \mathrm{ppm}$ and are strongly correlated with $\mathrm{Cl}$ (correlation coefficient $r=0.984$ ). Iodine (I) was found to be below the detection limit for all samples analysed except for sand SP45, which contains $1.1 \mathrm{ppm}$ I. Although the shell fragments were washed to remove sand and salt particles before crushing, they still contain $0.12 \% \mathrm{Cl}$, indicating its presence as inclusions in the shell itself. These results show that beach sand raw materials and seashell fragments can introduce some 'natron-related' elements such as $\mathrm{Cl}$ and $\mathrm{Br}$ to the glass batch.

\section{Sand-related elements}

The elements that are exclusively related to the sand raw materials are of particular interest for provenance studies of ancient glass. Two of those elements are $\mathrm{Zr}$ and $\mathrm{Hf}$, as they are almost entirely derived from the heavy mineral zircon. The $\mathrm{Zr}$ contents of the sands and shell analysed range from below the detection limit to $190 \mathrm{ppm}$. It must be noted, however, that the reported detection limits are rather high: $<16 \mathrm{ppm}$ for the shell material and $<68$ to $<220 \mathrm{ppm}$ for the sand samples. Concentrations of Hf vary between 1.01 and $5.35 \mathrm{ppm}$ in the sand. Shell material only contains $0.03 \mathrm{ppm}$ Hf. Zr and Hf are very strongly correlated $(r=0.995)$ with $\mathrm{Zr} / \mathrm{Hf}$ ratios between 30 and 40, typical for zircons derived from granites (Gulson 1969).

Next to $\mathrm{Zr}$ and $\mathrm{Hf}, \mathrm{TiO}_{2}$ is also generally related to the heavy mineral fraction in the sand raw materials and as a result they too are often correlated. The $\mathrm{TiO}_{2}$ contents range from 0.08 to $0.61 \%$. In a biplot of $\mathrm{TiO}_{2}$ versus $\mathrm{Zr}$, the expected correlation between the two elements is indeed present ( $r=0.948$; Fig. 3 (a)). Sand sample IT85, however, does not follow the same correlation and is relatively enriched in $\mathrm{Zr}$, reflecting a relative enrichment of zircon with respect to the Ti-rich mineral species, such as rutile, ilmenite and/or titanite, in the sand. Sc concentrations in the sands vary between 1.17 and $4.30 \mathrm{ppm}$. The $\mathrm{V}$ contents lie between 12.8 and $32.9 \mathrm{ppm}$. Moderate to good correlations of these elements with $\mathrm{Fe}_{2} \mathrm{O}_{3}$ and $\mathrm{TiO}_{2}$ suggest that they are also related to the heavy mineral fraction of the sand. The concentration of Ta in the beach sands varies between 0.18 and $0.48 \mathrm{ppm}$. Ta is relatively well correlated with other elements of group 4 and 5 of the periodic table, such as $\mathrm{TiO}_{2}(r=0.801), \mathrm{V}(r=0.676), \mathrm{Zr}(r=0.825)$ and $\mathrm{Hf}(r=0.786)$. The most common heavy mineral containing $\mathrm{Cr}$ is chromite. This mineral is generally associated with ultramafic igneous rocks. The Cr concentrations in the sands analysed in this study vary widely, between 8.2 and 277 ppm.

Concentrations of $\mathrm{Rb}$ range from 23.6 to $38.9 \mathrm{ppm}$ in the analysed sands. A correlation between $\mathrm{K}_{2} \mathrm{O}$ and $\mathrm{Rb}(r=0.847)$ indicates that $\mathrm{Rb}$ is present in $\mathrm{K}$-feldspar. Cs values range from 0.34 to $4.26 \mathrm{ppm}$, with sands IT34 and SP20 having the highest values. There is no clear correlation between $\mathrm{Cs}$ and the other alkali elements. The Ba concentrations in the sands vary between 95 and $280 \mathrm{ppm}$. Ba is often said to be related to alkali feldspar. However, the data show no correlation between $\mathrm{Ba}$ and $\mathrm{K}_{2} \mathrm{O}(r=0.182)$ or between $\mathrm{Ba}$ and $\mathrm{Rb}(r=-0.077)$. Although not very strong, correlations are present between $\mathrm{Ba}$ and $\mathrm{Sr}(r=0.816)$ and $\mathrm{Ba}$ and $\mathrm{Ca}(r=0.642)$. This suggests that $\mathrm{Ba}$ is not exclusively related to feldspars and that it can also be derived from the carbonate fraction of the beach sands. However, the shell material analysed in this study only contains $15 \mathrm{ppm} \mathrm{Ba}$. A connection to barite could not be investigated, since concentrations of $\mathrm{S}$ are not available.

Ga could only be detected in one sample, SP22, where it reaches $13 \mathrm{ppm}$. Detection limits for this element were, however, generally of the same order of magnitude. Concentrations of Th 

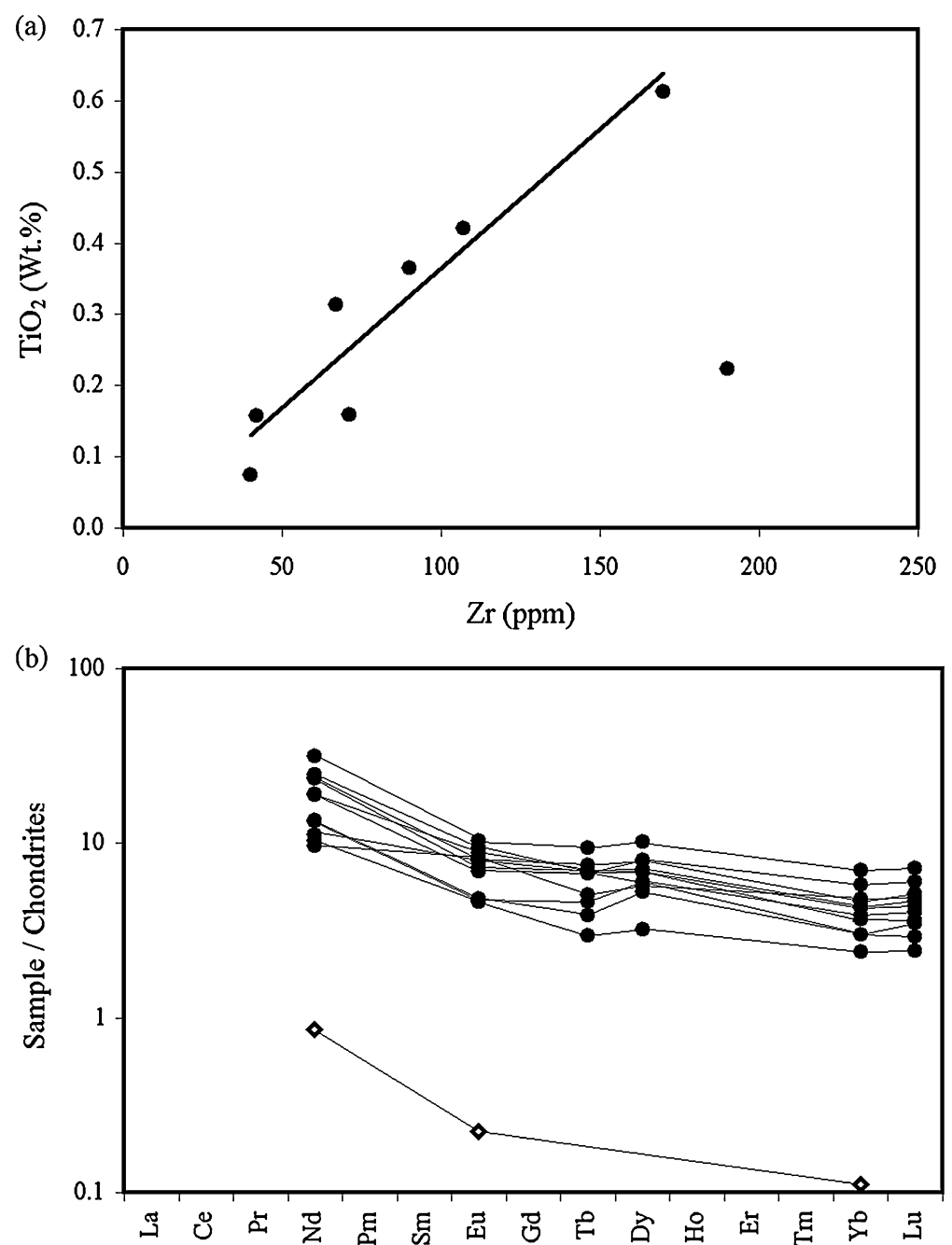

Figure 3 (a) The covariation of $\mathrm{Zr}$ with $\mathrm{TiO}_{2}$ in the analysed beach sands. The trendline $(r=0.948)$ is calculated after removal of sand IT85 from the data set. (b) The chondrite-normalized rare earth element patterns of the sands and shell analysed. The black dots are the sand samples and the open diamond is the shell material.

range from 1.55 to $5.45 \mathrm{ppm}$ in the sands. Th is correlated with $\mathrm{Zr}(r=0.839), \mathrm{Hf}(r=0.838)$ and the (heavy) rare earth elements $(r=0.726-0.739)$, indicating its presence in zircon (Wang et al. 2011; Nardi et al. 2012).

Rare earth element concentrations are chondrite-normalized using the values of Sun and McDonough (1989) and the REE patterns are shown in Figure 3 (b). Only Nd, Eu, Tb, Dy, Yb and Lu could be analysed. Ce was below the detection limit in all samples. The REE patterns of the sands are relatively flat, with a slight enrichment in light rare earth elements (LREE). Only sand sample FR17 shows a small positive Eu anomaly, consistent with its relatively high feldspar content (Brems et al. 2012c). For the other samples analysed, no significant Eu anomalies were found. The REE concentrations in the shell fragments are more than one order of magnitude 
lower than in the sands. The chondrite-normalized REE pattern of the shell material is similar to those of the sands, although possibly somewhat more enriched in LREE (Fig. 3 (b)).

\section{Lime-related elements}

The concentration of $\mathrm{Sr}$ in the sands analysed varies between 32 and $315 \mathrm{ppm}$, with a good correlation between $\mathrm{Sr}$ and $\mathrm{Ca}(r=0.892)$. The use of $\mathrm{Sr}$ isotope ratios and $\mathrm{Sr}$ concentrations for the provenancing of Roman natron glass, and especially the source of lime used, is extensively discussed by Brems et al. (2013a).

Shell fragments have relatively low concentrations of most of the trace elements analysed. Only $\mathrm{Sr}$ is strongly concentrated in shell $(1550 \mathrm{ppm}) . \mathrm{Cl}$ and $\mathrm{Br}$ are present in concentrations similar to those found in the sands. The other elements analysed occur in concentrations at least one order of magnitude smaller than in the sand samples. Results for the REE concentrations are comparable to those reported for clam shells from the North Sea by Wedepohl et al. (2011b).

\section{(De) colourant-related elements}

$\mathrm{Mn}$ and $\mathrm{Sb}$ are often present in elevated concentrations in Roman natron glass (Sayre and Smith 1961; Sayre 1963; Henderson 1985; Jackson 2005; Freestone 2008; Silvestri 2008; Foster and Jackson 2009). These elements were deliberately added to the batch to make the glass colourless by oxidizing iron, or to combine with other elements to create a variety of colours. The MnO concentration in the analysed sands ranges from 0.01 to $0.11 \%$. These values can be seen as the background level for $\mathrm{Mn}$, which can be attributed to the sand raw material (see also Brems et al. 2012c). Concentrations of $\mathrm{MnO}$ higher than $0.1 \%$ in natron glass are influenced by deliberate addition or by recycling. As an impurity in the $\mathrm{Mn}$ decolourizing agent, extra $\mathrm{Ba}$ is often introduced to the glass, resulting in a strong positive correlation between the two elements (Brill 1988; Jackson 2005; Silvestri 2008). The data presented in this study show no significant correlation between $\mathrm{MnO}$ and $\mathrm{Ba}(r=0.285)$. Sb contents of more than $37500 \mathrm{ppm}(4.99 \%$ $\mathrm{Sb}_{2} \mathrm{O}_{5}$ ) have been reported for natron glass (Arletti et al. 2006). Most of the sands analysed in this study contain low concentrations of Sb; that is, below 1.4 ppm. Only sand FR16 has higher Sb levels of $19.2 \mathrm{ppm}$. The Zn concentrations of most sands analysed vary between 5.3 and $84 \mathrm{ppm}$. Sand sample FR16, however, contains $272 \mathrm{ppm}$ of $\mathrm{Zn}$. The very high $\mathrm{Zn}$ and Sb contents in sand FR16 can be attributed to the former exploitation of a Pb-Zn-Ag deposit in Les Bormettes (Féraud 1983; Artignan and Nauchbaur 2007). Exploitation of this small-scale ore deposit had already commenced during the Gallo-Roman period and ended in 1908 (Artignan and Nauchbaur 2007). Erosion and redeposition of material from local tailings results in relatively high concentrations of metals in the local beach sand. Next to $\mathrm{Zn}$ and $\mathrm{Sb}$, soils in the area locally contain elevated concentrations of $\mathrm{Pb}, \mathrm{Cd}, \mathrm{Cu}$ and $\mathrm{Hg}$ (Artignan and Nauchbaur 2007).

Of all sands analysed, only SP22 contains measurable amounts of $\mathrm{Ni}$; that is, $21 \mathrm{ppm}$. Measured concentrations of $\mathrm{Co}$ in the sands vary between 1.1 and $4.5 \mathrm{ppm}$. The $\mathrm{Cu}, \mathrm{Se}$ and $\mathrm{Hg}$ concentrations are below the INAA detection limit for all samples analysed. Ag is below the detection limit for all samples except for sand IT85, which contains $0.80 \mathrm{ppm} \mathrm{Ag}$. Indium (In) is only above the detection limit in sand sample SP20, where it reaches $0.03 \mathrm{ppm}$.

\section{TRACE ELEMENTS AS A PROVENANCE INDICATOR FOR THE SILICA SOURCE?}

To determine the provenance of an archaeological glass artefact, we must find a measurable property that can link the glass to a particular production area. Most of the suitable sand raw 
materials from the western Mediterranean can be distinguished from those from the east by relying on their $\mathrm{Nd}$ isotopic composition (Brems et al. 2013b). Raw natron glass from Egypt and Syro-Palestine has relatively homogeneous $\varepsilon_{\mathrm{Nd}}$ values between -6.0 and -5.1 (Degryse and Schneider 2008; Freestone et al. unpublished data). Western Mediterranean beach sands mostly have lower $\varepsilon_{\mathrm{Nd}}$ values; that is, usually lower than -8 . However, Brems et al. (2013b) have shown that suitable sand raw materials from two locations in the south-east of Italy (IT85 and IT87) also have relatively high $\varepsilon_{\mathrm{Nd}}$ values, which coincide with those thought to be typical for raw glass produced in the eastern Mediterranean. Differences in trace element patterns may help to resolve this problem.

To evaluate the use of trace elements as a provenance indicator for Roman natron glass, we must compare the trace elemental signature of the sands analysed in this study to those of the known glass groups and raw materials from the eastern Mediterranean. For easier comparison, trace element data are often normalized to a common reference. In glass studies, this is usually the average continental Earth's crust (Freestone et al. 2002b; Wedepohl et al. 2011a,b). In this study, we use the average continental crust values of Wedepohl (1995).

Selected trace element data for raw natron glass and glass vessels from the ByzantineIslamic primary workshops at Bet Eli'ezer and Apollonia on the coast of Israel are given by Freestone et al. (2000). Their compositional profiles (Fig. 4 (a)) are relatively uniform, indicating the geochemical homogeneity of the sand sources along the Levantine coast (Freestone 2006). Average trace element patterns for Belus River sands are indeed very similar in shape (Fig. 4 (b); Brill 1988, 1999; Degryse previously unpublished; Table 2). Glasses from a workshop at Tel el-Ashmunein, Egypt, show a very different trace element distribution (Fig. 4 (c)). They are readily distinguished from the Syro-Palestinian glasses by their lower $\mathrm{Sr}$ and $\mathrm{Ba}$, and higher $\mathrm{Zr}$ concentrations (Freestone et al. 2000). The different origins of these glass groups was confirmed by $\mathrm{Sr}$ isotopic analysis, which suggested the use of shell-bearing beach sands for the production of the Syro-Palestinian glasses, and inland sand and limestone for the Egyptian glass (Freestone et al. 2003). Trace elemental compositions similar to those of the Syro-Palestinian raw glass were also found in glasses from Cyprus and AngloSaxon England (Freestone et al. 2002b; Freestone 2008). Other glasses-for example, from Carthage-have both high $\mathrm{Sr}$ and $\mathrm{Zr}$, indicating that their primary origin lies elsewhere (Freestone et al. 2000).

Sand raw material IT87 has an $\varepsilon_{\mathrm{Nd}}$ value of -4.17 (Brems et al. 2013b). This is higher than the $\varepsilon_{\mathrm{Nd}}$ values of -6.0 to -5.1 characteristic of raw natron glass from Israel (Degryse and Schneider 2008; Freestone et al. unpublished data). However, $\varepsilon_{\mathrm{Nd}}$ values as high as -1 have been reported for sands $400 \mathrm{~m}$ south of the mouth of the Belus River (Degryse and Schneider 2008) and Nile River sediments (Goldstein et al. 1984; Weldeab et al. 2002; Scrivner et al. 2004). Therefore, it is very likely that a suitable sand source with such high $\varepsilon_{\mathrm{Nd}}$ values also exists along the Syro-Palestinian coast. Sand raw material IT85 has an $\varepsilon_{\mathrm{Nd}}$ value of -6.11 (Brems et al. 2013b). Trace element signatures of these Italian sands are shown in Figure 4 (d). The two trace element patterns are markedly different. Sand IT87 generally has the lower concentration of trace

Figure 4 (following page) Trace element concentrations normalized to the mean abundances in the Earth's continental crust (Wedepohl 1995). The black lines are sand samples and grey lines represent glass samples. (a) Syro-Palestinian raw glass chunks from Bet Eli'ezer and Apollonia, and glass vessels from Apollonia (Freestone et al. 2000); (b) Belus River sand (superscripts in parentheses: 1, Degryse previously unpublished; 2, Brill 1988, 1999); (c) Egyptian glass from Tell el-Ashmunein (Freestone et al. 2000); (d) sand samples IT85 and IT87; $(e)$ sand samples IT01 and IT34; $(f)$ sand samples SP46, SP45 and SP43; $(g)$ sand samples FR16 and FR17; $(h)$ sand samples SP2O and SP22. 
Trace element analysis in provenancing Roman glass-making

(a)

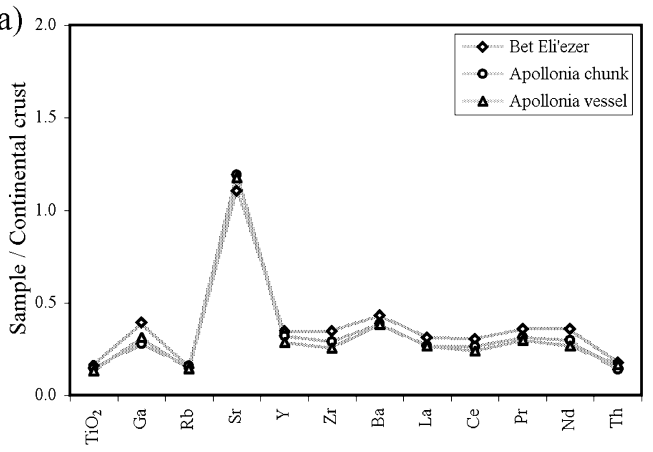

(c)

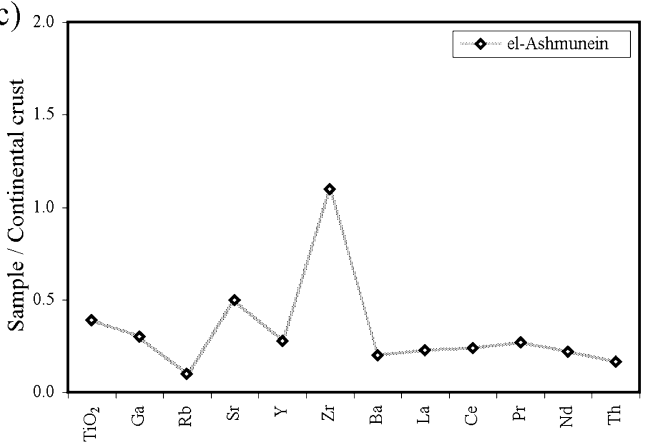

(e)

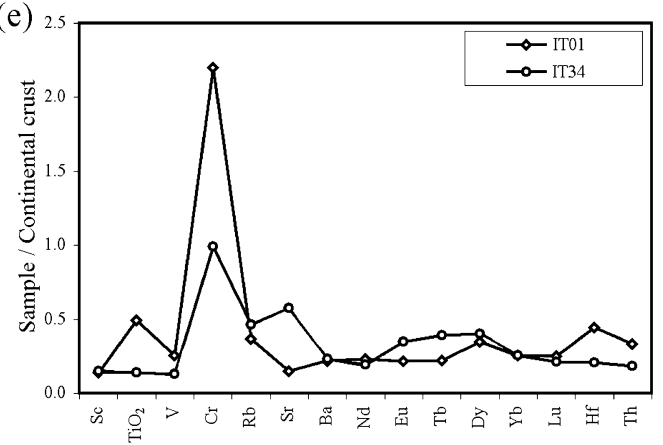

(g)

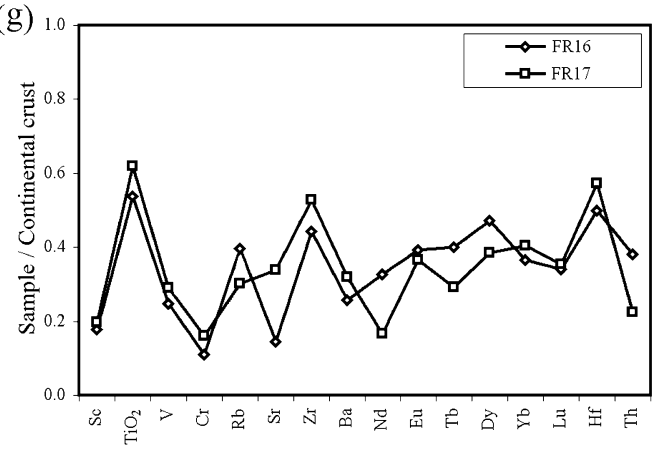

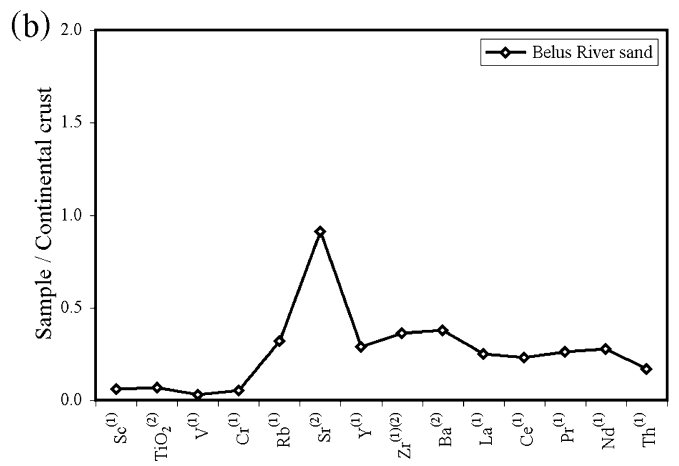
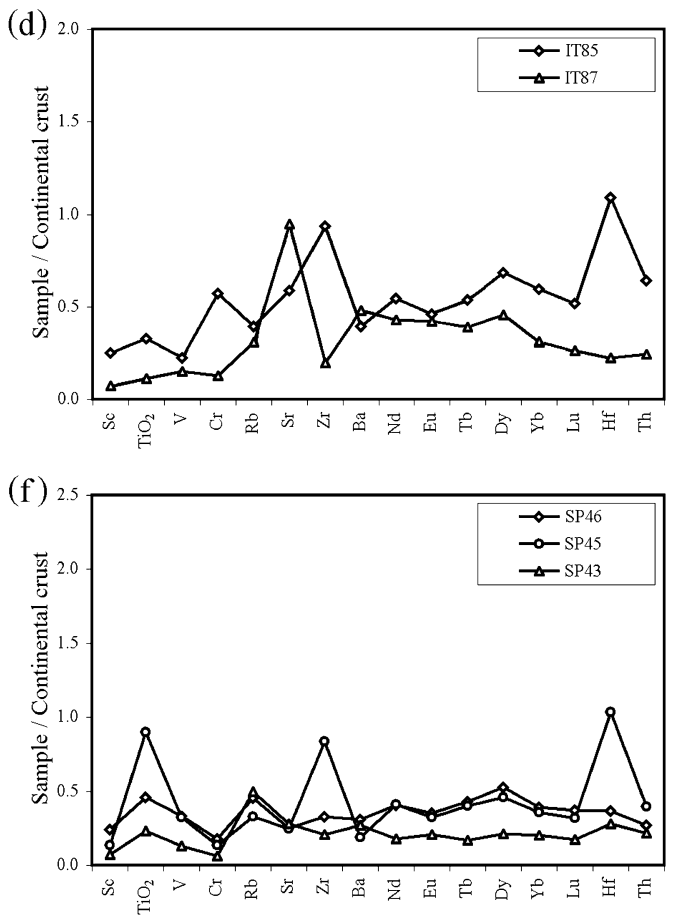

(h)

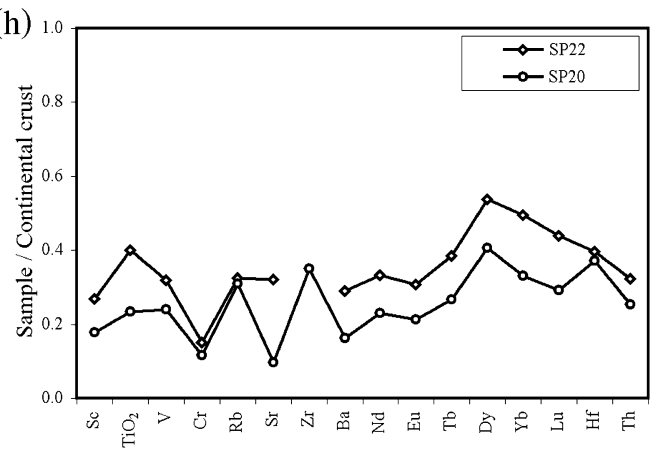


elements. Only $\mathrm{Sr}$ and $\mathrm{Ba}$ are relatively elevated. Concentrations of $\mathrm{TiO}_{2}, \mathrm{Cr}$ and $\mathrm{Zr}$ are very low. Sand sample IT85 generally contains higher concentrations of heavy minerals and the associated trace elements $\mathrm{TiO}_{2}, \mathrm{Cr}, \mathrm{Zr}, \mathrm{Hf}$ and REE. When comparing Figures 4 (a), 4 (b) and 4 (d), the trace element pattern of sand IT87 appears to be very similar to those of Syro-Palestinian raw glass and Belus River sands. However, IT87 is even more depleted in Zr. Another important difference lies in the characteristically low $\mathrm{Al}_{2} \mathrm{O}_{3}$ content of sand IT87, which resulted in $\mathrm{Al}_{2} \mathrm{O}_{3}$ contents lower than $1.5 \%$ in the glass (see Brems et al. 2012c). This is significantly lower than the $\mathrm{Al}_{2} \mathrm{O}_{3}$ concentrations of 2.2-3.2\% in Belus River sand (Brill 1988, 1999) and 2.5-4.0\% generally found in the Syro-Palestinian glass made from that sand (Freestone et al. 2000). Sand raw material IT85 can be easily distinguished from Belus River sand by its higher $\mathrm{TiO}_{2}, \mathrm{Cr}$ and $\mathrm{Zr}$ contents, and lower Sr. Sand IT85 has ${ }^{87} \mathrm{Sr} /{ }^{86} \mathrm{Sr}$ isotope ratios higher than the modern seawater value, while Egyptian glass has relatively low Sr isotopic signatures (Freestone et al. 2003; Brems et al. 2013a; Fig. 5).

Other suitable sand raw materials along the coasts of the western Mediterranean all have significantly lower $\varepsilon_{\mathrm{Nd}}$ values (Brems et al. 2013b). These sand sources can be further separated on the basis of their $\varepsilon_{\mathrm{Nd}}$ values and trace element signatures (Fig. 5). Italian sands IT01 and IT34 have similar Nd isotopic signatures as suitable (low lime) sand raw materials from the south-west of Spain (SP46, SP45 and SP43). The $\varepsilon_{\mathrm{Nd}}$ values of these sands all lie between -9.40 and -7.99 (Brems et al. 2013b). IT01 and IT34 can be distinguished from each other by their different $\mathrm{TiO}_{2}$ and $\mathrm{Cr}$ contents (Fig. 4 (e)). Sand IT01 is also much lower in Sr, a result of the very low calcium carbonate content of this sand. After the addition of extra shell fragments as a source of lime, glasses produced from these two sands would have similar Sr concentrations (Brems et al. 2013a). Trace element signatures of the Spanish sands vary according to their heavy mineral contents (Fig. 4 (f)). Sample SP43 is the most pure quartz sand and has very low concentrations of, for example, $\mathrm{TiO}_{2}, \mathrm{Zr}$, Hf and REE. Sands SP46 and especially SP45 contain more heavy minerals and have relatively elevated $\mathrm{TiO}_{2}, \mathrm{Zr}$, Hf and REE. The most distinguishing feature between the Italian and Spanish sands is the $\mathrm{Cr}$ content. The Italian sand samples contain on average 12 times more $\mathrm{Cr}$ than the Spanish sands.

Suitable glass-making sand raw materials from south-eastern Spain (SP22 and SP20) and south-eastern France (FR16 and FR17) all have $\varepsilon_{\mathrm{Nd}}$ values lower than -10 (Brems et al. 2013b). Trace element signatures of the French sands are shown in Figure $4(\mathrm{~g})$. Sand sample FR17 has slightly higher concentrations of most trace elements. Rb and Th, however, are higher in FR16 and also the REE pattern is somewhat different, with an enrichment of Eu in FR17. Sand samples SP22 and SP20 have trace element patterns with very similar shapes (Fig. 4 (h)). The pattern of SP22 is generally shifted to higher concentrations. This sand also contains relatively elevated $\mathrm{Fe}_{2} \mathrm{O}_{3}$ and $\mathrm{Al}_{2} \mathrm{O}_{3}$ levels. SP20 shows two pronounced peaks for $\mathrm{Zr}$ and $\mathrm{Hf}$, indicating a relative enrichment of the heavy mineral zircon. These peaks are absent in the SP22 trace element pattern. The two sand samples from the south-east of France contain, on average, higher concentrations of $\mathrm{TiO}_{2}$ and also the $\mathrm{TiO}_{2} / \mathrm{V}$ ratio is different, with $0.014-0.016$ for French sands and $0.006-0.009$ for Spanish sands.

\section{CONCLUSIONS}

In this study, we have evaluated the use of trace elements as a provenance indicator for Roman natron glass. It was shown that the combined use of $\mathrm{Nd}$ isotopic signatures, major elements (particularly $\mathrm{Al}_{2} \mathrm{O}_{3}$ ) and trace element patterns makes it possible to distinguish between the different possible sources of suitable sand raw materials in the regions under investigation. The 


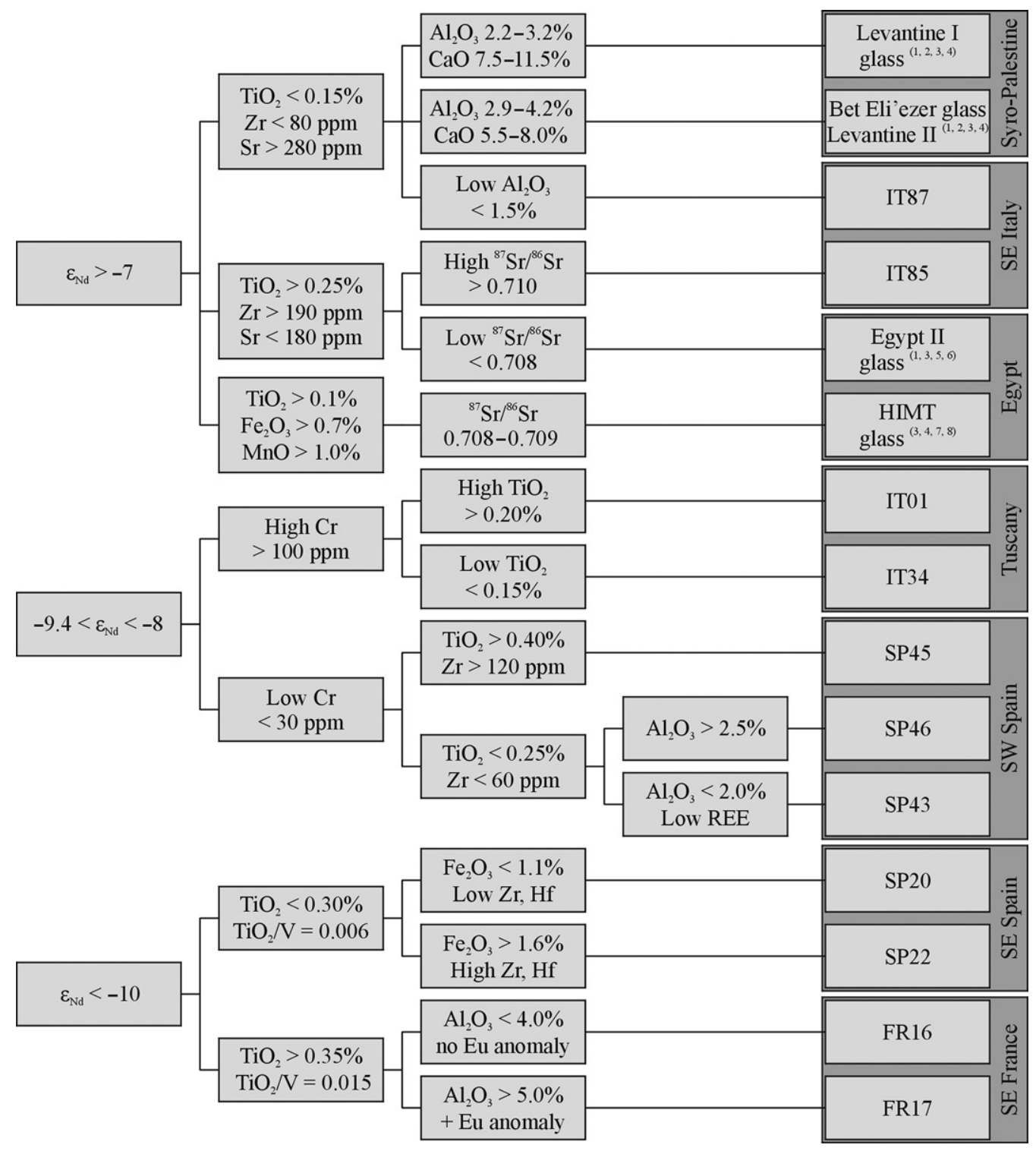

Figure 5 A flowchart for determining the provenance of natron glass (superscripts in parentheses: 1, Freestone et al. 2000; 2, Freestone 2006; 3, Degryse and Schneider 2008; 4, Freestone et al. unpublished data; 5, Gratuze and Barrandon 1990; 6, Freestone et al. 2003; 7, Freestone et al. 2005; 8, Foster and Jackson 2009).

trace elements that proved to be the most diagnostic are $\mathrm{Ti}, \mathrm{Cr}, \mathrm{Sr}, \mathrm{Zr}$ and $\mathrm{Ba}$. Apart from $\mathrm{Ba}$ (and possibly Sr), which is often associated with Mn decolourants, these elements are seldom influenced by the addition of colouring agents or recycling, and should provide direct information about the nature of the silica source used. However, since data for possible sand sources from areas such as Corsica, Sardinia, North Africa, Greece, Turkey and Cyprus are not yet available, 
the existence of competing Roman glass producers with overlapping elemental and isotopic characteristics in these areas cannot be excluded nor confirmed.

Slightly elevated concentrations in glass of trace elements commonly associated with colouring agents, such as $\mathrm{Mn}, \mathrm{Co}, \mathrm{Ni}, \mathrm{Cu}, \mathrm{Zn}, \mathrm{Sb}$ and $\mathrm{Pb}$, are often interpreted as the result of recycling of glass cullet. The analysis of these elements in suitable glass-making sands provides a good idea of the background levels that can be attributed to impurities in the source of silica. The current data set suggests that for the two most commonly used decolourizers, $\mathrm{MnO}$ and $\mathrm{Sb}$, these background levels are $0.1 \%$ and $30 \mathrm{ppm}$ respectively. The presence of higher amounts of these elements in Roman glass would indicate their deliberate or accidental (due to recycling of cullet) addition. Additional detailed analysis of a wider range of trace elements in suitable sand raw materials can only provide further insights into the influence of the different raw materials on the composition of ancient natron glass. Also, trace elemental data of materials typically used as colourants in antiquity are essential to evaluate their contribution to the final trace elemental composition of the glass. In particular, their influence on the concentration of elements commonly attributed to the sand source should be investigated to make sure that these elements are indeed only derived from the sand raw material and are therefore potentially useful as provenance indicators. To our knowledge, data of this kind are not available at the moment.

\section{ACKNOWLEDGEMENTS}

We are grateful to Steven Luypaers, Johan Honings and Elvira Vassilieva for help with the sample preparation and ICP-OES analyses. Menno Blaauw and Mehmet Sarilar of the Delft University of Technology are thanked for providing the INAA data. Dr Robert Brill is warmly acknowledged for providing the Belus sand samples. The research is financially supported by the ERC Starting Grant ARCHGLASS Grant agreement no. 240750 and the FWO project no. 6.0864.09. Dieter Brems benefitted from a Research Assistant Grant of the Fund for Scientific Research-Flanders (FWO-Vlaanderen) and is currently working as postdoctoral fellow of the Fund for Scientific Research-Flanders (FWO-Vlaanderen).

\section{REFERENCES}

Aerts, A., Velde, B., Janssens, K., and Dijkman, W., 2003, Change in silica sources in Roman and post-Roman glass, Spectrochimica Acta, Part B, 58, 659-67.

Arletti, R., Dalconi, M. C., Quartieri, S., Triscari, M., and Vezzalini, G., 2006, Roman coloured and opaque glass: a chemical and spectroscopic study, Applied Physics A: Materials Science \& Processing, 83, 239-45.

Artignan, D., and Nauchbaur, A., 2007, Mine Pb-Zn-Ag des Bormettes et du Verger Concessions des Bormettes et de La Londe-les-Maures (Var), Unpublished report, Bureau de Recherches Géologiques et Minières (BRGM) RP-55548FR.

Bamford, C. R., 1977, Colour generation and control in glass, Glass Science and Technology 2, Elsevier, Amsterdam.

Bateson, H. M., and Turner, W. E. S., 1939, A note on the solubility of sodium chloride in a soda-lime-silica glass, Journal of the Society of Glass Technology, 23, 265-7.

Bode, P., 1990, Instrumental neutron activation analysis in a routine way, Journal of Trace and Microprobe Techniques, 8, 139-54.

Brems, D., Degryse, P., Ganio, M., and Boyen, S., 2012a, The production of Roman glass with western Mediterranean sand raw materials: preliminary results, Glass Technology: European Journal of Glass Science and Technology A, 53, 129-38.

Brems, D., Boyen, S., Ganio, M., Degryse, P., and Walton, M., 2012b, Mediterranean sand deposits as a raw material for glass production in Antiquity, in Annales du $18^{e}$ Congrès de l'Association Internationale pour l'Histoire du Verre, Thessaloniki, 120-7, AIHV, Thessaloniki. 
Brems, D., Degryse, P., Hasendoncks, F., Gimeno, D., Silvestri, A., Vassilieva, E., Luypaers, S., and Honings, J., 2012c, Western Mediterranean sand deposits as a raw material for Roman glass production, Journal of Archaeological Science, 39, 2897-907.

Brems, D., Ganio, M., Latruwe, K., Balcaen, L., Carremans, M., Gimeno, D., Silvestri, A., Vanhaecke, F., Muchez, P., and Degryse, P., 2013a, Isotopes on the beach Part 1-Strontium isotope ratios as a provenance indicator for lime raw materials used in Roman glassmaking, Archaeometry, 55, 214-34.

Brems, D., Ganio, M., Latruwe, K., Balcaen, L., Carremans, M., Gimeno, D., Silvestri, A., Vanhaecke, F., Muchez, P., and Degryse, P., 2013b, Isotopes on the beach, Part 2: Neodymium isotopic analysis for provenancing Roman glassmaking, Archaeometry, 55, 449-64.

Brill, R. H., 1988, Scientific investigations of the Jalame glass and related finds, in Excavations at Jalame: site of a glass factory in Late Roman Palestine (ed. G. D. Weinberg), 257-94, University of Missouri Press, Columbia, MO.

Brill, R. H., 1999, Chemical analyses of early glasses, Corning Museum of Glass, Corning, New York.

Cullers, R., Chaudhuri, S., Kilbane, N., and Koch, R., 1979, Rare-earths in size fractions and sedimentary rocks of Pennsylvanian-Permian age from the mid-continent of the USA, Geochimica et Cosmochimica Acta, 43, $1285-301$.

Currie, K. J., 2008, Analytical elemental fingerprinting of natron and its detection in ancient Egyptian mummified remains, Unpublished Ph.D. thesis, University of Manchester.

Degryse, P., and Schneider, J., 2008, Pliny the Elder and Sr-Nd isotopes: tracing the provenance of raw materials for Roman glass production, Journal of Archaeological Science, 35, 1993-2000.

Degryse, P., and Shortland, A., 2009, Trace elements in provenancing raw materials for Roman glass production, Geologica Belgica, 12, 135-43.

Degryse, P., Schneider, J., Lauwers, V., De Muynck, D., Vanhaecke, F., Waelkens, M., and Muchez, Ph., 2006, Sr and Nd isotopic evidence in the primary provenance determination of Roman glass from Sagalassos (SW Turkey), in Annales du $17^{e}$ Congrès de l'Association Internationale pour l'Histoire du Verre, Anvers (eds. K. H. A. Janssens, P. Degryse, P. Cosyns, J. Caen and L. Van't dack), 564-70, University Press Antwerp, Antwerp.

Féraud, J., 1983, Ore veins linked to old emersion surfaces in the crystalline basement of Provence and of the external belt of the French-Italian Alps, in Mineral deposits of the Alps and of the Alpine Epoch in Europe (ed. H. J. Schneider), 128-35, Special Publication 3, Society for Geology Applied to Mineral Deposits, Prague.

Foster, H. E., and Jackson, C. M., 2009, The composition of 'naturally coloured' late Roman vessel glass from Britain and the implications for models of glass production and supply, Journal of Archaeological Science, 36, 189-204.

Foster, H. E., and Jackson, C. M., 2010, The composition of late Romano-British colourless vessel glass: glass production and consumption, Journal of Archaeological Science, 37, 3068-80.

Freestone, I. C., 2006, Glass production in Late Antiquity and the Early Islamic period: a geochemical perspective, in Geomaterials in cultural heritage (eds. M. Maggetti and B. Messiga), 201-16, Special Publications 257, Geological Society of London, London.

Freestone, I. C., 2008, Pliny on Roman glassmaking, in Archaeology, history and science. integrating approaches to ancient materials (eds. M. Matinón-Torres and T. Rehren), 77-100, UCL Institute of Archaeology Publications, Oxford.

Freestone, I. C., Gorin-Rosen, Y., and Hughes, M. J., 2000, Primary glass from Israel and the production of glass in the late antiquity and the early Islamic period, in La route du verre: ateliers primaires et secondaires de verriers du second millénaire avant J.C. au Moyen Age (ed. M.-D. Nenna), 65-83, Travaux de la Maison de l'Orient Méditerranéen 33, Lyon.

Freestone, I. C., Greenwood, R., and Gorin-Rosen, Y., 2002a, Byzantine and early Islamic glassmaking in the eastern Mediterranean: production and distribution of primary glass, in Hyalos = vitrum = glass: history, technology and conservation of glass and vitreous materials in the Hellenic world, proceedings of the first international conference, Rhodes, Greece, 1-4 April 2001 (ed. G. Kordas), 167-74, Glasnet Publications, Athens.

Freestone, I. C., Ponting, M., and Hughes, J., 2002b, Origins of Byzantine glass from Maroni Petrera, Cyprus, Archaeometry, 44, 257-72.

Freestone, I. C., Leslie, K. A., Thirlwall, M., and Gorin-Rosen, Y., 2003, Strontium isotopes in the investigation of early glass production: Byzantine and early Islamic glass from the Near East, Archaeometry, 45, 19-32.

Freestone, I. C., Wolf, S., and Thirlwall, M., 2005, The production of HIMT glass: elemental and isotopic evidence, in Annales du $16^{e}$ Congrès de l'Association Internationale pour l'Histoire de Verre, London, 153-7, AIHV, Nottingham.

Ganio, M., Boyen, S., Brems, D., Scott, R., Foy, D., Latruwe, K., Molin, G., Silvestri, A., Vanhaecke, F., and Degryse, P., 2012, Trade routes across the Mediterranean: a $\mathrm{Sr} / \mathrm{Nd}$ isotopic investigation on Roman colourless glass, Glass Technology: European Journal of Glass Science and Technology A, 53, 217-24.

Gerth, K., Wedepohl, K., and Heide, K., 1998, Experimental melts to explore the technique of medieval woodash glass production and the chlorine content of medieval glass types, Chemie der Erde, 58, 219-32. 
Goldstein, S. L., O’Nions, R. K., and Hamilton, P. J., 1984, A Sm-Nd isotopic study of atmospheric dusts and particulates from major river systems, Earth and Planetary Science Letters, 70, 221-36.

Gorin-Rosen, Y., 1995, Hadera, Bet Eli'ezer, Excavations and Surveys in Israel, 13, 42-3.

Gorin-Rosen, Y., 2000, The ancient glass industry in Israel: summary of finds and new discoveries, in La route du verre: ateliers primaires et secondaires du second millénaire avant J.C. au Moyen Age (ed. M.-D. Nenna), 49-64, Travaux de la Maison de l'Orient Méditerranéen 33, Lyon.

Gratuze, B., and Barrandon, J.-N., 1990, Islamic glass weights and stamps: analysis using nuclear techniques, Archaeometry, 32, 155-62.

Green, L. R., and Hart, F. A., 1987, Colour and chemical composition in ancient glass: an examination of some Roman and Wealden glass by means of ultraviolet-visible-infra-red spectrometry and electron microprobe analysis, Journal of Archaeological Science, 14, 271-82.

Greenberg, R. R., Bode, P., and De Nadai Fernandes, E. A., 2011, Neutron activation analysis: a primary method of measurement, Spectrochimica Acta, Part B, 66, 193-241.

Gromet, L. P., and Silver, L. T., 1983, Rare earth element distributions among minerals in a granodiorite and their petrogenetic implications, Geochimica et Cosmochimica Acta, 47, 925-39.

Gulson, B. L., 1969, Electron microprobe determination of $\mathrm{Zr} / \mathrm{Hf}$ ratios in zircons from the Yeoval Diorite Complex, N.S.W., Australia, Lithos, 3, 17-23.

Henderson, J., 1985, The raw materials of early glass production, Oxford Journal of Archaeology, 4, $267-91$.

Jackson, C. M., 2005, Making colourless glass in the Roman period, Archaeometry, 47, 763-80.

Köpsel, D., 2001, Solubility and vaporization of halides, in Proceedings of International Congress on Glass, vol. 2, Extended abstracts, 330, Society of Glass Technology, Edinburgh.

Lidiak, E. G., and Jolly, W. T., 1996, Rare earth elements in the geological sciences, in Episodes from the history of the rare earth elements (ed. C. H. Evans), 149-87, Kluwer Academic, Dordrecht.

McKay, G. A., 1989, Partitioning of rare earth elements between major silicate minerals and basaltic melts, in Geochemistry and mineralogy of rare earth elements (eds. B. R. Lipin and G. A. McKay), 45-77, Reviews in Mineralogy 21, Mineralogical Society of America, Chantilly, VA.

McLennan, S. M., 1989, Rare earth elements in sedimentary rocks: influence of provenance and sedimentary processes, in Geochemistry and mineralogy of rare earth elements (eds. B. R. Lipin and G. A. McKay), 169-200, Reviews in Mineralogy 21, Mineralogical Society of America, Chantilly, VA.

Nardi, L. V. S., Formoso, M. L. L., Jarvis, K., Oliveira, L., Bastos Neto, A. C., and Fontana, E., 2012, REE, Y, Nb, U, and Th contents and tetrad effect in zircon from a magmatic-hydrothermal F-rich system of Sn-rare metalecryolite mineralized granites from the Pitinga Mine, Amazonia, Brazil, Journal of South American Earth Sciences, 33, 34-42.

Paynter, S., 2006, Analyses of colourless Roman glass from Binchester, County Durham, Journal of Archaeological Science, 33, 1037-57.

Pollard, A. M., and Heron, C., 2008, Archaeological chemistry, 2nd edn, The Royal Society of Chemistry, London.

Reade, W., 2009, A compositional study of Late Bronze Age and Iron Age glasses from the Near East, Unpublished Ph.D. thesis, The University of Sydney.

Salviulo, G., Silvestri, A., Molin, G., and Bertoncello, R., 2004, An archaeometric study of the bulk and surface weathering characteristics of Early Medieval (5th-7th century) glass from the Po valley, northern Italy, Journal of Archaeological Science, 31, 295-306.

Sayre, E. V., 1963, The intentional use of antimony and manganese in ancient glasses, in Advances in glass technology, part 2 (eds. F. R. Matson and G. Rindone), 263-82, Plenum Press, New York.

Sayre, E. V., and Smith, R. V., 1961, Compositional categories of ancient glass, Science, 133, 1824-6.

Scrivner, A. E., Vance, D., and Rohling, E. J., 2004, New neodymium isotope data quantify Nile involvement in Mediterranean anoxic episodes, Geology, 32, 565-8.

Shahid, K. A., and Glasser, F. P., 1972, Phase equilibria in the system Na-Ca-Mg-Si, Physics and Chemistry of Glasses, 13, 27-42.

Shannon, R. D., 1976, Revised effective ionic radii and systematic studies of interatomic distances in halides and chalcogenides, Acta Crystallographica, A32, 751-67.

Shortland, A. J., 2004, Evaporites of the Wadi Natrun: seasonal and annual variation and its implication for ancient exploitation, Archaeometry, 46, 497-516.

Shortland, A. J., Rogers, N., and Erimin, K., 2007, Trace element discriminants between Egyptian and Mesopotamian Late Bronze Age glasses, Journal of Archaeological Science, 34, 781-9.

Shortland, A. J., Schachner, L., Freestone, I. C., and Tite, M., 2006, Natron as a flux in the early vitreous materials industry: sources, beginnings and reasons for decline, Journal of Archaeological Science, 33, 521-30. 
Shortland, A., Degryse, P., Walton, M., Geer, M., Lauwers, V., and Salou, L., 2011, The evaporitic deposits of Lake Fazda (Wadi Natrun, Egypt) and their use in Roman glass production, Archaeometry, 53, 916-29.

Shugar, A., and Rehren, Th., 2002, Formation and composition of glass as a function of firing temperature, Glass Technology, 43C, 145-50.

Silvestri, A., 2008, The coloured glass of Iulia Felix, Journal of Archaeological Science, 35, 1489-501.

Silvestri, A., Molin, G., and Salviulo, G., 2005, Roman and medieval glass from the Italian area: bulk characterization and relationships with production technologies, Archaeometry, 47, 797-816.

Silvestri, A., Molin, G., and Salviulo, G., 2008, The colourless glass of Iulia Felix, Journal of Archaeological Science, 35, 331-41.

Sun, S.-s., and McDonough, W. F., 1989, Chemical and isotopic systematics of oceanic basalts: implications for mantle composition and processes, 313-45, Special Publications 42, Geological Society, London.

Tlig, S., and Steinberg, M., 1982, Distribution of rare-earth elements (REE) in size fractions of recent sediments of the Indian Ocean, Chemical Geology, 37, 317-33.

Walton, M. S., Shortland, A., Kirk, S., and Degryse, P., 2009, Evidence for the trade of Mesopotamian and Egyptian glass to Mycenaean Greece, Journal of Archaeological Science, 36, 1496-503.

Wang, X., Griffin, W. L., Chen, J., Huang, P., and Li, X., 2011, U and Th contents and Th/U ratios of zircon in felsic and mafic magmatic rocks: improved zircon-melt distribution coefficients, Acta Geologica Sinica, 85, 164-74.

Wedepohl, K. H., 1995, The composition of the continental crust, Geochimica et Cosmochimica Acta, 59, 1217-32.

Wedepohl, K. H., and Baumann, A., 2000, The use of marine molluskan shells for Roman glass and local raw glass production in the Eifel area (Western Germany), Naturwissenschaften, 87, 129-32.

Wedepohl, K. H., Simon, K., and Kronz, A., 2011a, Data on 61 chemical elements for the characterization of three major glass compositions in Late Antiquity and the Middle Ages, Archaeometry, 53, 81-102.

Wedepohl, K. H., Simon, K., and Kronz, A., 2011b, The chemical composition including the rare earth elements of the three major glass types of Europe and the Orient used in late antiquity and the Middle Ages, Chemie der Erde, 71, 289-96.

Weldeab, S., Emeis, K. C., Hemleben, C., and Siebel, W., 2002, Provenance of lithogenic surface sediments and pathways of riverine suspended matter in the eastern Mediterranean Sea: evidence from ${ }^{143} \mathrm{Nd} /{ }^{144} \mathrm{Nd}$ and ${ }^{87} \mathrm{Sr} /{ }^{86} \mathrm{Sr}$ ratios, Chemical Geology, 186, 139-49.

Weyl, W. A., 1951, Coloured glasses, Society of Glass Technology, Sheffield.

Yokoo, Y., Nakano, T., Nishikawa, M., and Quan, H., 2004, Mineralogical variation of Sr-Nd isotopic and elemental compositions in loess and desert sand from the central Loess Plateau in China as a provenance tracer of wet and dry deposition in the northwestern Pacific, Chemical Geology, 204, 45-62. 